Svitlana Boychenko, Doctor of Geography, Associated Professor, Leading Researcher of S.I. Subbotin Institute of Geophysics of the NAS of Ukraine / Associated Professor of the Head of Department of Environmental Studies, National University of «Kyiv-Mohyla Academy» (Kyiv, Ukraine) $)^{1}$

Lidiia Horoshkova, Doctor of Economics, Associated Professor, Professor of the Department of Business, Management Organizations and Logistics, Zaporizhzhia National University

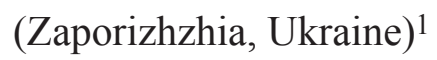

Liubov Zharova, Doctor of Economics, Senior Scientist, Head of Department of International Economic Relations, Business and Management of the Ukrainian-American Concordia University (Kyiv, Ukraine) / University of Economics and Humanities (Bielsko-Biala, Poland) ${ }^{1}$

Viktor Karamushka, Ph.D. in Biology, Associated Professor, Head of Department of Environmental Studies, National University of «Kyiv-Mohyla Academy» (Kyiv, Ukraine) ${ }^{1}$

Ievgen Khlobystov, Doctor of Economics, Professor of the Department of Environmental Studies, National University of «Kyiv-Mohyla Academy» (Kyiv, Ukraine) / University of Economics and Humanities (Bielsko-Biala, Poland) ${ }^{1}$

Michał Śleziak, Rector, University of Economics and Humanities (Bielsko-Biala, Poland) ${ }^{1}$

\title{
NATURAL AND ECONOMIC SYSTEM: MANAGEMENT IN CONDITIONS OF CLIMATE CHANGES
}

Abstract: It is proved in the study that united territorial communities (UTC) can be considered as a complex natural and economic nonlinear, dynamic system capable for self-governance.

It is proved that quantitative measurement of equilibrium is economic efficiency-Pareto efficiency, which requires optimal resources allocation among market players for production, taking into account their scarcity and limited products with their unlimited consumption.

It is found out that management of internal opportunities and external impact interconnections creates the background for UTCs sustainable development. The main infrastructural components of UTCs sustainable development are economic, environmental and social ones.

It is shown that the economic component of sustainable development is supported by the current mechanism of UTCs financial resources formation, which ensures stability and self-sufficiency of territorial communities. From the ecological component standpoint, sustainable development should ensure the integrity of biological and physical natural

\footnotetext{
1 Affiliated to University of Economics and Humanities (Bielsko-Biała, Poland)
} 
systems, their viability, which affects global stability of the entire biosphere. The social component is focused on human development, preserving social and cultural systems stability, reducing the number of conflicts.

It is proved that current climate change is a paramount factor of the external environment, which seriously affects the parameters of UTCs 'natural and economic system functioning. General analysis of the vulnerability of Ukraine's natural and economic systems (NES) to climate change has been conducted. It is confirmed that climate change affects different sectors of national economy, but this it is not unequivocal.

The expediency of finding new innovative management and business technologies is substantiated. It is shown that startups carrying-out within and in the interests of UTCs has several positive characteristics in social, economic and environmental context.

Keywords: incorporated united territorial community, sustainable development, innovative technologies, natural and economic systems, management

\section{Problem statement and its connection with other important and practical tasks.}

A comprehensive vision of the reforms required by the Ukrainian society is presented in the «Strategy for Sustainable Development of Ukraine-2020» approved by the Decree of the President of Ukraine [Ukaz Prezydenta Ukrainy, 2015]. Among the priorities of the Strategy are decentralization and reformation of national social and economic system, restructuring of business entities` territorial organization giving maximum geographical considerations. In accordance with the goals of Sustainable Development, adapted for Ukraine (during 2015 - 2030s) [Tsili Staloho Rozvytku: Ukraina. Natsionalna dopovid, 2017], the goal 11 concerning sustainable development of cities and communities is directly related to the process of decentralization. Goal 1 - End poverty in all its forms everywhere, Goal 2 End hunger, achieve food security and improved nutrition and promote sustainable agriculture, Goal4-Ensureinclusiveand equitablequalityeducationand promotelifelonglearningopportunities for all, Goal 6 - Ensure availability and sustainable management of water and sanitation for all, Goal 7-Ensure access to affordable, reliable, sustainable and modern energy for all, Goal 9-Build resilient infrastructure, promote inclusive and sustainable industrialization and foster innovation, Goal 14 - Conserve and sustainably use the oceans, seas and marine resources for sustainable development, Goal 15 - Protect, restore and promote sustainable use of terrestrial ecosystems, sustainably manage forests, combat desertification, and halt and reverse land degradation and halt biodiversity loss and Goal 17 - Partnership for Sustainable Development are related to it. 
Nowadays the problem of strong united territorial communities (UTCs) formation in the context of administrative and territorial reform implementation based on the principles of decentralization becomes especially acute. Resources are the paramount factor for the development of capable and sustainable communities.

\section{Analysis of recent studies or publications initiated solution}

\section{to the problem and used by the author.}

Pavliuk Y. P., Oliinyk D. I., Batanov O.A., Dashko O.I., Murkovych L. L., Molodozhen Y.B. and other scholars studied current aspects of territorial communities`and local self-government`s development problems solution [Batanov, 2008; Murkovych, 2010; Molodozhen, 2006]. Own findings concerning the problem are presented in [Volkov, Horoshkova, Karbivnychyi R., 2018; Volkov, Horoshkova, Karbivnychyi I., 2018; Volkov, Karbivnychyi I., Karbivnychyi R, Horbova, 2018; Horoshkova, Volkov, Kapranova, Komelina, 2018; Horoshkova, Volkov, 2018; Khlobystov, 2016; Khlobystov, 2016; . Huseva, Segeda, Khlobystov, 2015].

\section{The article is dedicated to the identified unsolved problems.}

The new administrative and territorial system should become the basis for constructing a new model of territorial administration, based on the principles of decentralization, subsidiarity, balance of national interests with regional and territorial communities' interests representation, local self-governance widespread, territorial communities` power and autonomy, coherence with natural geographical capacity. That is why the problem of UTCs resource management and their sustainable development conditions deserves special attention.

\section{Setting objectives of the article.}

Development of conceptual foundations of the management system for sustainable development of natural and economic systems, illustrated by the example of united territorial communities.

\section{The main material of the research with justified scientific results.}

According to the Law of Ukraine «On Local Self-Government in Ukraine» (statutory wording of 02.08.2017), «the territorial community is presented by residents permanently residing within a village, settlement, city, which is an autonomous administrative and territorial devision, or a voluntary association of residents of several villages having a single administrative center» [Zakon Ukrainy,1997]. 
Hence, UTC is a complex natural and economic nonlinear, dynamic system able for selfgovernance [Dudnyk, 2009]:

1. Infinity of the system learning. It is impossible to fully understand the system, it is possible to offer some of its structural and functional options, reflecting its various aspects.

2. Interaction with the external environment. External environment affects system development, but retains its special, inherent properties.

3. Integrity (emergence). System components function together, they are interconnected, create new properties. Properties of the system as a whole cannot be reduced to the sum of properties of its elements.

4. The hierarchy of the system. Each element of a complex system is an independent system, but it is also an integral part of the overall system.

5. Structure. Each system has elements that form a certain dynamic structure. Dynamism provides the ability to system changes and development.

6. Components. The primary component of the system is also a system, but its structure is not considered at this level of analysis.

Additional properties (characteristics) of a complex system are:

1. System status. It is formed due to the states of its elements, it can be changed both continuously or in discrete steps.

2. System behaviour. The system is able to move from one state to another. Each has certain properties and structure.

3. Continuity of functioning. The property is inherent in dynamic systems. All inner processes are interrelated. A complex system functions as a whole, and vice versa. It is accompanied by continuous changes, the accumulation of which provides the development.

4. System development. It is caused by subsystems` and elements` pass through different stages of functioning and development. Both components and the system as a whole are renovated.

5. Dynamism. Economic systems function and evolve over time, have certain stages of their development, and a life cycle.

6. Compilation. Systems are formed by heterogeneous elements and subsystems, there are connections between them. This provides their multivariate properties and development.

7. Homeostasis. The systems ability to self-preservation, the ability to counteract the destroying external environment.

8. Purposefulness. Setting the objective of its existence. Change of goals acts as the source of development. 
9. Guidance. Realized, targeted functioning of a system and its elements. Gives the possibility of solving contradictions that arise in the system. It is targeted self-organization, which provides the possibility of self-development while maintaining system's quality determinacy.

10. Adaptability. Ability to self-regulation (passive adaptation) and management for effective functioning (active).

11. The response rate. The system complexity leads to slow respond to the impact issues, time (lag).

12. Stability (sustainability). The system behavior and status do not change significantly with little influence within certain limits. They consider system`s structure sustainability and the trajectory of its behavior. Sustainability is supported by self-organization, namely its properties - differentiation and lability (sensitivity). Differentiation is system ability to solve contradictions, adapt to changes in the environment due to structural diversity. Lability is functions mobility of system elements with its total sustainability.

13. The state of equilibrium. System sustainability is connected with its aptitude to equilibrium. Equilibrium is the state of maximum system efficiency, that is, the main purpose of its functioning. A complex system cannot achieve full equilibrium as its constituent elements function in different conditions and dynamically interact with one another. Having achieved a certain equilibrium, the system avoids it. In some special cases, bifurcations can emerge that remove the system from the equilibrium. Thus, the stable (sustainable) economic system fluctuates near the equilibrium, moving from one equilibrium state to another, that is, it is in a dynamic equilibrium that ensures its development.

Hence, UTC is an open, dynamic system that is not in equilibrium. Relevant management processes are mutually consistent with its components (subsystems). J. Schumpeter proved that outbalanced economic system does not return to it [Shumpeter, 1982]. It moves to another stationary state of equilibrium at a qualitatively new level of development. The transition mechanism is a combination of new methods for more efficient use of available resources to create capital and non-capital goods.

Dynamic equilibrium is optimal for a complex system. It is formed based on interactions of two opposite trends in production and consumption growth. Equilibrium is characterized by a certain organizational structure of the economic system. Quantitatively it is characterized by the effectiveness of economic relations. 
The instability of complex systems is one of the managerial tasks for creating prerequisites for stable dynamic development. The systems are capable for self-governance. Management of systems self-organization is a source of their accelerated development, as a result the selection of qualities, features and properties that increase the level of system organization in the process of adaptation to external environments occur. To ensure system development there is a need to maintain its sustainability applying management instruments. The state of maximum stability of the dynamic equilibrium is the state of system equilibrium with the maximum possible efficiency (Pareto-efficiency) [Klebanov et all, 2004 ]. Pareto-efficiency is the maximum possible efficiency of resources and products distribution, i.e. the indicator of marginal stability of economic system`s equilibrium. The minimum possible efficiency is an indicator of the marginal minimum stability of economic system`s equilibrium.

A quantitative measure of equilibrium is economic efficiency - Pareto-efficiency [Klebanov et all, 2004], which requires an optimal resources distribution among market players for production, taking into account their scarcity and limited products with their unlimited consumption. In non-equilibrium (crisis) conditions, the Pareto-efficiency principle is violated. The problem of resource allocation is important for UTCs, since resource support is the basis of UTCs dynamic development.

In the process of its development there is a quantitative accumulation of system efficiency. After reaching the maximum for a certain period of development (Pareto-efficiency), the redistribution causes new state of disorganization. At the same time, there is a change in the values of efficiency or the ratio of production and consumption indices from maximum to minimum.

Management of interconnections between internal capabilities and external impact creates conditions for UTCs sustainable development. The main infrastructural components of UTCs sustainable development are economic, environmental and social.

Economic component of sustainable development is provided by current mechanism for the formation of UTCs financial resources, which ensures stability and self-sufficiency of territorial communities.

From the ecological component standpoint, sustainable development must ensure the integrity of biological and physical natural systems, their viability, which depends on the global stability of the entire biosphere.

The social component is focused on human development, maintenance of social and cultural systems stability, reduction of conflicts number. 
System harmonization and the balance of these three components form enormously complex challenge. Its result is reflected in the «Methodology for the formation of communities capacity» [Postanova Kabinetu Ministriv Ukrainy, 2015]: a powerful territorial community is a territorial community of villages (settlements, cities), which, as a result of a voluntary association, can independently or through appropriate local self-government bodies provide an adequate level of service provision, in particular in the sphere of education, culture, health care, social protection, housing and utilities infrastructure, taking into account human resources, financial support and infrastructure development of the corresponding administrative division.

But the ecological component itself needs, in our opinion, additional attention.

Current climate change is a key factor of external environment that significantly influences the parameters of UTCs natural and economic system functioning. These changes have already led to the manifestation of a number of negative consequences in the geophysical, geochemical and biological systems of the Earth (sea level rise, desertification, degradation of the polar and mountain glaciers, increasing volatility and abnormality of weather conditions, etc.), which affected the human socio-economic sphere (agriculture, energy production, urban environment, etc.). According to the UN Intergovernmental Panel on Climate Change, the average annual air temperature rose by $\sim 0.85{ }^{\circ} \mathrm{C} / 100$ years during $1880-2012 \mathrm{~s}$ [IPCC:Climate change, 2013]. According to a more optimal scenario, taking into account levels of greenhouse gases concentration in the atmosphere and in case of their concentration doubling by the end of the XXI ${ }^{\text {st }}$ century, it is expected that the temperature will increase within $\sim 1.5-2.5^{\circ} \mathrm{C}$ [IPCC: Climate change, 2013].

At the United Nations Climate Change Conference in Paris (December 12, 2015), the agreement concerning intentions to achieve a significant reduction in greenhouse gas emissions and thus to keep the global average annual temperature in the range from $1.5-2{ }^{\circ} \mathrm{C}$ was approved. Signatories from Ukraine undertook a commitment to reduce $\mathrm{CO}_{2}$ emissions by at least $30 \%$ by 2030 and adopt the integrated approach to mitigation and adaptation to climate change [Dosvid Yevropeiskoho Soiuzu v adaptatsii do zminy klimatu ta zastosuvannia yoho v Ukraini, 2012].

The climate of Ukraine has definitely been affected by the global climate change. In the $\mathrm{XX}^{\text {th }}$ century and in the beginning of the $\mathrm{XXI}^{\text {st }}$ century the average annual temperature has increased by $1.0 \pm 0.2{ }^{\circ} \mathrm{C} / 100$ years, annual atmospheric precipitation in the territory of Ukraine has not changed significantly, but their significant territorial and seasonal redistribution has taken place [Boychenko, 2018]. Besides there is a typical decrease in the amplitude of seasonal 
temperature fluctuations: serious warming in the cold season of the year to $0.4 \pm 0.1{ }^{\circ} \mathrm{C} /$ 100 years. Recent decades have been marked by the increase in frequency and duration of summer heat (abnormally high temperatures above $30^{\circ} \mathrm{C}$ ) followed by an important decrease in precipitation) [Boychenko, 2016].

Let us conduct general analysis of weakness of Ukraine's natural and economic systems (NES) for climate change.

Climate change undoubtedly affects different fields of national economy, but it is worth noting the ambiguity of these impacts in various areas.

Agriculture. On the one hand, there is an improvement in climatic conditions (temperature increase in the cold season, decrease in the number of frosty days, increase in the duration of the growing season, etc.), which leads to higher yields. On the other hand, deterioration (decrease in the amount of precipitation and abnormally high summer temperatures, alternation of long dry periods with heavy rainfall, significant climate variability) requires an alternative transition from no irrigated agriculture to irrigation one, introduction of new adapted plants, pest and disease control of crops and livestock, implementation of ecological agriculture, using optimal amount of pesticides and mineral fertilizers and ecologization of the processing industry [Demianenko, Butko, 2012]. Therefore, forecasts indicate that average annual temperature rise to $1{ }^{\circ} \mathrm{C}$ causes reduction in agricultural production by $5-10 \%$ [Kucher, 2017; Stratehiia nyzkovuhletsevoho rozvytku Ukrainy do 2050 roku, 2015].

Moreover, agriculture is a source of greenhouse gas emissions from economic activities in this area, and therefore low-carbon agricultural land use is a strategic development priority. Estimated reduction of $\mathrm{CO}_{2}$ emissions in agriculture by $17 \%$ in Ukraine by 2020 (from total $\mathrm{CO}_{2}$ emissions in 2013) [Kucher, 2017]. At the same time, high $\mathrm{CO}_{2}$ concentration in the atmosphere leads to the development of class $\mathrm{C}_{3}$ yield of crops. Scenario scores for the $21^{\text {st }}$ century of the major agricultural crop yields in the context of global warming at $2-3{ }^{\circ} \mathrm{C}$ and doubling $\mathrm{CO}_{2}$ emissions in the atmosphere give positive assessments for the agrosphere of Ukraine (for $\mathrm{C}_{3}$ plants (wheat, soybean, rice, etc.) yields rise by $15-20 \%$, but $\mathrm{C}_{4}$ plants (sorghum, corn, sugarcane) yields do not change) [IPCC: Climate change, 2013].

Water resources. Climate aridization (rise of surface temperature and low amount of atmospheric precipitation, especially in summer), intensive water use and pollution can lead to negative impacts on water resources. A critical shortage of water resources will increase the vulnerability of agriculture, water power engineering, shipping and affect the population health. Although the reduction of river runoff can lead to contraction in flooding frequency 
and scale, during long arid periods, sudden heavy rainstorms can provoke strong flooding and underflooding (because of higher share of impervious surface (pavement), decline of imperviousness and water absorption into the ground, loss of green area that holds water in the ground) [Dosvid Yevropeiskoho Soiuzu v adaptatsii do zminy klimatu ta zastosuvannia yoho v Ukraini, 2012].

Implementation of some policies to prevent water crisis (accumulation of water in multifunctional reservoirs, boost of territory`s water storage capacity, optimization of geosystems structure in river basins).

Energy production. The total energy and industrial $\mathrm{CO}_{2}$ emissions rose to $37 \mathrm{Gt}$ by 2016 , and reached a 41 Gt level in 2017 [https://phys.org/news/2017-11-global-carbon-dioxide-emissions-stable.html]. The main strategic objective is the transition of Ukraine's economy to low carbon growth based on sustainable development.

Problems faced by the power industry in the context of climate change provoked by changes in the thermal regime and the regime of humidification, reduction of river runoff (natural-biased and caused by the increased water intakes) would have a direct impact on hydraulic power industry and nuclear and thermal power plants cooling [Dosvid Yevropeiskoho Soiuzu v adaptatsii do zminy klimatu ta zastosuvannia yoho v Ukraini, 2012].

Warming in the cold season reduces the need for heating, but at the same time, there is a growing need for cooling air in the summer.

Transport. One of the main climate change factors is greenhouse gas emissions from transport sector (up to $25 \%$ of total emissions). Moreover, transport is a source of air and noise pollution.

The main areas of climate change impact are: abnormal atmospheric rainfall and rainstorm (precipitation exceeds standard level by 2-3 times) give rise to underflooding (transport collapse) over outdated drain systems and drainage; abnormal temperature rise above 28-35 degrees leads to intensive use of air conditioning systems, which creates additional network loading, road surface begins to melt and fail, traffic is significantly limited over rails deformation (for example, in hot summer days some road sections of the railways were heated to $53-55^{\circ} \mathrm{C}$, and in some places up to $57^{\circ} \mathrm{C}$ ); sagging, breaking and short circuit of power lines, deteriorating working conditions pose risks in traffic and driver's health risk [Transport i zminy klimatu. Stalyi rozvytok transportnoi systemy., 2016; Kucher, 2017; Karpenko, Beznisko, Chernavtsev, 2011]. 
Coastal territories. Climate change led to the Black and Azov seas level rise (in the $\mathrm{XX}^{\text {th }}$ century the level rose by $0.15-0.20 \mathrm{~m}$, and with further warming by the end of the $\mathrm{XX}^{\text {th }}$ century, one can expect seas level rise by $0.5-1.0 \mathrm{~m}$ ) will cause intensive coastal erosion and marine ecosystems degradation, changes in the species composition, algal bloom. This is a problem for the population, infrastructure and recreation [IPCC: Climate change, 2013; Dosvid Yevropeiskoho Soiuzu v adaptatsii do zminy klimatu ta zastosuvannia yoho v Ukraini, 2012; Demianenko, Butko, 2012]. Wearing away of the Black and Azov Seas coastline is vulnerable to the processes of abrasion (when raising its level by $1 \mathrm{~cm}$ the shore is flooded by $1-2 \mathrm{~m}$, which in future may lead to part of coastal areas losses, including the unique Black Sea and Azov's sand bars [Boychenko, 2016].

Biodiversity. The biodiversity around Ukraine (especially of steppes, forests, delta rivers and coastal zones) is greatly affected by current climate and human impact, which may induce changes in species composition and even loss of some species, increase in the number of pests, fire development. [Tkachenko, Boichenko, 2014]. Forest expansion will increase the absorption by $3.5 \times 10^{6} \mathrm{t} \mathrm{CO}_{2 \mathrm{eq}}$. Besides, absorption level will rise more as a result of greater phytomass of newly formed forests [IPCC: Climate change,2013].

Health of the population. Warm winters affected by global climate change do not create preconditions for increasing mortality and morbidity due to cold, but abnormal summer heat and serious changes in weather conditions during the cold season increase risks to human health and lead to cardiovascular disease (makes up about $60 \%$ of deaths in the country) [Ofitsinyi vebsait proektu Climate Forum East. Chervonyi khrest, 2013-2014; WHO. Highlights on health in Ukraine, 2005]. The population of Ukraine is not adapted to survive intense heat, which goes with heat discomfort. Activation of climate-sensitive pathogenic microorganisms and endemic situations are likely to rise.

Urban environment. Climate changes produce larger and more powerful abnormal phenomena that cause direct (physical) influences (flooding, abnormal heat, etc.) and indirect processes and phenomena that complicate functioning of individual urban business divisions and reduce the quality basic services supply for the population (water supply, energy supply, etc.). The peculiarities of climate change manifestations in large cities are more threatening than in other types of settlements (towns and villages). Thus, the manifestation of certain natural hydrometeorological phenomena (snowfall, ice, rainstorms and snowstorms) may become a complete collapse for various business entities and large city dwellers, whereas village and towns residents may be less affected, and sometimes face no impact at all. Further- 
more, specific microclimatic effects are being formed in the cities (thermal effect "island" of heat, photochemical smog, local zones with high air turbulence, etc.) [Dosvid Yevropeiskoho Soiuzu v adaptatsii do zminy klimatu ta zastosuvannia yoho v Ukraini, 2012].

For example, abnormal atmospheric precipitation (rainstorms) affects urban infrastructure functioning (buildings, roads, sewage and power systems) and the comfort, prosperity and life security of city dwellers.

The Covenant of Mayors for Climate and Energy states that the main potential negative climate impact that may occur in Ukrainian cities include: abnormal weather conditions, including thermal stress, underflooding, natural hydrometeorological phenomena, growing scarcity and deterioration quality of drinking water, increased number of infectious and cardiovascular diseases, exacerbation of allergy, deforestation and plant species disorder, traffic and energy systems breach [https://phys.org/news/2017-11-global-carbon-dioxide-emissions-stable.html].

A comprehensive understanding of the impacts`consequences, risks and weaknesses as well as activities coordination at national, regional and local levels is needed to develop appropriate climate change adaptation measures and policy programs [Dosvid Yevropeiskoho Soiuzu v adaptatsii do zminy klimatu ta zastosuvannia yoho v Ukraini, 2012; Karpatskyi instytut rozvytku (Koshytse, Slovachchyna), 2015 Ahentstvo spryiannia stalomu rozvytku Karpatskoho rehionu «FORZA» (Uzhhorod, Ukraina), 2015].

The assessment of UTCs vulnerability to certain negative climate impacts is based on vulnerability indicators, which are divided into specific groups according to different principles (territory vulnerability to thermal stress and underflooding, settlements`green spaces vulnerability, vulnerability to natural hydrometeorological phenomena, vulnerability of quality and growing scarcity of potable water, vulnerability to the increased number of infectious diseases and allergy, the vulnerability of urban energy systems). After identifying the level of vulnerability to a specific climate impact, UTCs develop adaptation activity included to natural and economic system development.

Taking into account the specifics of natural and economic systems at mesolevel (UTCs), it is expedient to search for new innovative technologies of management and business. Let us consider some of them.

Startup is one of these innovative business forms. It is a newly created company (perhaps not yet officially registered but plans to obtain formal registration), which does its business on the basis of innovation or innovative technologies, has not entered the market or has begun to enter it and which has scarce resources. An important incentive to attract start-upers (innova- 
tors) to the ecosystem is the creation of an integral «green» complex and constant advancement of its advantages such as: access to resources, communications and ideas exchange, common data and contacts base, etc. Considering that the principles of voluntary association of territorial communities are, in particular, economic efficiency, state support, transparency, openness, and responsibility, then the formation of friendly environment naturally complements fundamental principles of UTCs founding. The basis for the environment's success is the maximum consideration and application of the existing infrastructure features, as well as analysis and challenges stating for the new business models.

Thus, carrying-out of start-ups within and in the interests of UTCs has several positive characteristics in social, economic and environmental context. The main ones are: opportunity of effective and rapid ways to solve local problems (to put in practice one of the fundamental principles of sustainable development - think globally - do locally), investment attraction, development of innovative ecological environment: organization of cooperation of all interested parties and infrastructure development, positive information dissemination about UTCs success, which may contribute to their economic development in the future, in particular due to the increased investment attractiveness of a community, raising communities awareness concerning problems (including environmental), and the ways of their solution in a profitable and effective way, active participation of a community in implementation of sustainable development goals and in international organizations`activities.

\section{Study results.}

It is proved in the study that UTC can be considered as a complex natural and economic nonlinear, dynamic system capable for self-governance. Its main properties are: infinity of the system learning; interaction with the external environment; integrity (emergence); hierarchy of the system; structure; available components; has a certain status and behaviour; continuity of functioning; system developmental; dynamism; compilation; homeostasis; purposefulness; guidance; adaptability; the response rate; stability (sustainability); equilibrium. It is shown that the state of dynamic equilibrium and volatility, as the prerequisites for dynamic development are optimal for UTCs.

It is proved that quantitative measurement of equilibrium is economic efficiency - Pareto efficiency, which requires optimal resources allocation among market players for production, taking into account their scarcity and limited products with their unlimited consumption. 
It is found out that management of internal opportunities and external impact interconnections creates the background for UTCs sustainable development. The main infrastructural components of UTCs sustainable development are economic, environmental and social ones.

It is shown that the economic component of sustainable development is supported by the current mechanism of UTCs financial resources formation, which ensures stability and self-sufficiency of territorial communities. From the ecological component standpoint, sustainable development should ensure the integrity of biological and physical natural systems, their viability, which affects global stability of the entire biosphere. The social component is focused on human development, preserving social and cultural systems stability, reducing the number of conflicts.

It is proved that current climate change is a paramount factor of the external environment, which seriously affects the parameters of UTCs`natural and economic system functioning. General analysis of the vulnerability of Ukraine's natural and economic systems (NES) to climate change has been conducted. It is confirmed that climate change affects different sectors of national economy, but this it is not unequivocal.

The expediency of finding new innovative management and business technologies is substantiated. It is shown that startups carrying-out within and in the interests of UTCs has several positive characteristics in social, economic and environmental context. Among the main ones are: opportunity of effective and rapid ways to solve local problems (to put in practice one of the fundamental principles of sustainable development - think globally - do locally), investment attraction, development of innovative ecological environment: organization of cooperation of all interested parties and infrastructure development, positive information dissemination about UTCs success, which may contribute to their economic development in the future, in particular due to the increased investment attractiveness of the community, raising communities awareness concerning problems (including environmental), and the ways of their solution in a profitable and effective way, active participation of a community in implementation of sustainable development goals and in international organizations` activities.

The future prospects for research are to identify and assess current and potential impacts, to determine value characteristics of potential damage to the regional economy and life support systems. This will allow to determine current and potential impacts on environment, health of the population and the economy as well, provide guidance to authorities and local communities to prevent adverse changes caused by human-induced impacts and climate change, propose adaptation activity. 


\section{References}

1. Boychenko S., Voloshchuk V., Kuchma T., Serdyuchenko N. (2018), Long-time changes of the thermal continentality index, the amplitudes and the phase of the seasonal temperature variation in Ukraine. Geofizicheskiy Zhurnal. V.40, N3. P.81-96. https://doi.org/10.24028/gzh.0203-3100.v40i3.2018.137175

2. Boychenko S., Voloshchuk V., Movchan Ya., Serdjuchenko N., Tkachenko V., Tyshchenko O., Savchenko S. (2016), Features of climate change in Ukraine: scenarios, consequences for nature and agroecosystems. Proceedings of the National Aviation University. No 4. P. 96-113. https://doi.org/10.18372/2306-1472.69.11061

3. Horoshkova L., Volkov V., Kapranova L., Komelina A. (2018), The Reverse Subsidy`s Impact of United Territorial Community`s Budget Generations. International Journal of Engineering \& Technology. № 7(4.8). P. 539-543.

4. https://phys.org/news/2017-11-global-carbon-dioxide-emissions-stable.html.

5. IPCC:Climate change 2013: The Physical Science Basis, 2013. Working Group I Contribution to the Fifth Assessment Report of the Intergovernmental Panel on Climate, UNEP/WMO. URL: http://www.ipcc.ch/report/ar5/wg1/.

6. Volkov V.P., Karbivnychyi I.O, Karbivnychyi R.O., Horbova I.A. (2018). Conditions of the no-loss functioning of territorial formation. Belostok: Belostok. $190 \mathrm{p}$.

7. WHO. Highlights on health in Ukraine. 2005. URL: http://www.euro.who.int/_data/assets/pdf_file/0016/103615/E88285.pdf .

8. Batanov O.V. Terytorialna hromada - pervynnyi subiekt munitsypalnoi vlady v Ukraini: poniattia ta oznaky. URL: http://www.cvk.gov.ua/visnyk/pdf/2008_2/visnik_st_13.pdf .

9. Volkov V. P., Horoshkova L. A., Karbivnychyi I. O. (2018). Naukovi zasady tekhnolohii upravlinnia resursamy komunalnoi vlasnosti v umovakh reformuvannia.

Belostok: Belostok. 138 s.

10. Volkov V. P., Horoshkova L. A., Karbivnychyi R. O. (2018). Upravlinnia nerukhomistiu terytorialnykh hromad. Belostok: Belostok. $144 \mathrm{~s}$

11. Horoshkova L. A., Volkov V. P. (2018). Upravlinnia finansovymy protsesamy detsentralizatsii ta formuvannia terytorialnykh hromad. Ekonomichnyi visnyk PereiaslavKhmelnytskoho derzhavnoho pedahohichnoho universytetu. № 36/1. C. 285-293.

12. Horoshkova L. A., Volkov V.P., Karbivnychyi R.O. (2018) Rol mizhbiudzhetnoho rehuliuvannia u finansovii spromozhnosti terytorialnykh hromad. Visnyk Pryazovskoho derzhavnoho tekhnichnoho universytetu. Seriia: Ekonomichni nauky. № 36. C. 5-12.

13. Huseva I. I., Segeda I.V., Khlobystov Ie.V. (2015). Ekolohizatsiia enerhetyky u zabezpechenni staloho rozvytku derzhavy / za nauk. redaktsiieiu d.e.n., prof. Khlobystova Ie.V. / NTUU «KPI», ITHIP NANU, The University of Economics and Humanities. - Kyiv - Bielsko-Biala: vydavets Chabanenko Yu.A. 276 s. 
14. Demianenko S., Butko V. (2012). Stratehiia adaptatsii ahrarnykh pidpryiemstv Ukrainy do hlobalnykh zmin klimatu. Ekonomika Ukrainy. № 6. S. 66-72.

15. Derzhavna ekolohichna polityka Ukrainy v umovakh detsentralizatsii vlady / za nauk. red. d.e.n., prof. Ye.V. Khlobystova (2016). Derzhavna ustanova «Instytut ekonomiky pryrodokorystuvannia ta staloho rozvytku Natsionalnoi akademii nauk Ukrainy». Kyiv: DU IEPSR NAN Ukrainy. 226 s.

16. Dosvid Yevropeiskoho Soiuzu v adaptatsii do zminy klimatu ta zastosuvannia yoho v Ukraini (Erikom E. Masseiem) Biuro Koordynatora z ekonomichnoi ta dovkilnoi diialnosti OBSIe, 2012. URL: https://www.osce.org/uk/ukraine/104020.

17. Dudnyk I.M. (2009). Vstup do zahalnoi teorii system. K.:Kondor. 205 s.

18. Zakon Ukrainy «Pro mistseve samovriaduvannia v Ukraini». URL: http://www.Zakon2.rada.gov.ua/lows/show/280/97-вр.

19. Karpatskyi instytut rozvytku (Koshytse, Slovachchyna), 2015. Ahentstvo spryiannia stalomu rozvytku Karpatskoho rehionu «FORZA» (Uzhhorod, Ukraina).

20. Karpenko O. A., Beznisko V. P., Chernavtsev A. Yu. (2011). Vplyv nehatyvnykh klimatychnykh tendentsii na transportnu infrastrukturu. Upravlinnia proektamy, systemnyi analiz i lohistyka. Vyp. 8. S. 305-307.URL: http://nbuv.gov.ua/UJRN/Upsal_2011_8_83ю

21. Klebanov T.S., Dubrovyna N.A., Poliakova O.Iu., Raevneva E.V., Mylov A.V., Serhyenko E.A. (2004). Modelyrovanye эkonomycheskoi dynamyky. Kh.:Yzdatelskyi Dom «NZhЭK». $244 \mathrm{~s}$.

22. Kucher A. (2017). Adaptatsiia ahrarnoho zemlekorystuvannia do zmin klimatu. Agricultural and Resource Economics : International Scientific E-Journal. Vol. 3. No. 1. P. 119-138. URL: www.are-journal.com.

23. Molodozhen Yu.B. (2006) Poniattia i sutnist terytorialnoi hromady v systemi mistsevoho samovriaduvannia Ukrainy. Universytetski naukovi zapysky: Chasopys Khmelnytskoho universytetu. № 2. S. 128-136.

24. Murkovych L. Terytorialna hromada yak subiekt mistsevoho samovriaduvannia v Ukraini: teoretychni aspekty. URL: http://www.dbuapa.dp.ua/vidavnictvo/2010/2010_02\%285\%29/10mliuta.pdf

25. Ofitsiinyi vebsait proektu Climate Forum East. Chervonyi khrest., 2013-2014 rr. URL: www.climateforumeast.org.

26. Pro zatverdzhennia Metodyky formuvannia spromozhnykh terytorialnykh hromad: Postanova Kabinetu Ministriv Ukrainy vid 8 kvitnia 2015 r. № 214. ).

URL: http://zakon2.rada.gov.u

27. Stratehiia nyzkovuhletsevoho rozvytku Ukrainy do 2050 roku. URL: https://menr.gov.ua/files/docs/Proekt/LEDS_ua_last.pdf. 
28. Terytorialna hromada yak bazova lanka administratyvno-terytorialnoho ustroiu Ukrainy: problemy ta perspektyvy reformuvannia (2016). Kyiv: NISD. $61 \mathrm{~s}$.

29. Tkachenko V. S., Boichenko S.H. (2014). Strukturnyi dreif stepovykh fitosystem Ukrainy pid vplyvom klimatychnykh zmin ta prohnostychni stsenarii dlia pershoi polovyny KhKhI stolittia. Dopovidi Natsionalnoi akademii nauk Ukrainy. № 4. S. 172-180.

30. Transport i zminy klimatu. Stalyi rozvytok transportnoi systemy. Zbirnyk materialiv dlia politykiv. URL: http://climategroup.org.ua/?p=1145

31. Ukaz Prezydenta Ukrainy «Pro Stratehiiu staloho rozvytku «Ukraina - 2020» (vid 12 sichnia 2015 r., № 5/2015). URL: http://zakon5.rada.gov.ua/laws/show/5/2015.

32. Khlobystov Ye.V. (2016). Osoblyvosti formuvannia ta rozvytku mizhnarodnoi ekolohichnoi polityky Ukrainy za umov detsentralizatsii vriaduvannia // Stalyi rozvytok KhKhI stolittia: upravlinnia, tekhnolohii, modeli. Dyskusii 2016: kolektyvna monohrafiia [Anderson V.M., Baldzhy M. D., Barkan V.I. ta in.] / NTUU «Kyivskyi politekhnichnyi instytut»; Instytut telekomunikatsii ta hlobalnoho informatsiinoho prostoru NAN Ukrainy; Vyshcha ekonomiko-humanitarna shkola / za nauk. red. Khlobystova Ye.V. Cherkasy. S. 228-234.

33. Tsili Staloho Rozvytku: Ukraina. Natsionalna dopovid. Ministerstvo ekonomichnoho rozvytku i torhivli Ukrainy.

URL: http://un.org.ua/images/SDGs_NationalReportUA_Web_1.pdf

34. Shumpeter Y. (1982). Teoryia эkonomycheskoho razvytyia. M.: Prohress. 456 s. 